\title{
Article \\ Relationship between Microstructure and Properties of 1380 MPa Grade Bainitic Rail Steel Treated by Online Bainite-Based Quenching and Partitioning Concept
}

\author{
Miao Liu ${ }^{1}$, Yusong Fan ${ }^{1}$, Xiaolu Gui ${ }^{1}$, Jie $\mathrm{Hu}^{2}{ }^{2}$, Xi Wang ${ }^{1}$ and Guhui Gao ${ }^{1, *(D)}$ \\ 1 School of Mechanical, Electronic and Control Engineering, Beijing Jiaotong University, Beijing 100044, China; \\ 20126033@bjtu.edu.cn (M.L.); 20116051@bjtu.edu.cn (Y.F.); xlgui@bjtu.edu.cn (X.G.); \\ wangxi@bjtu.edu.cn (X.W.) \\ 2 Metals \& Chemistry Research Institute, China Academy of Railway Sciences Corporation Limited, \\ Beijing 100081, China; hujierails@163.com \\ * Correspondence: gaogh@bjtu.edu.cn
}

check for

updates

Citation: Liu, M.; Fan, Y.; Gui, X.; Hu, J.; Wang, X.; Gao, G. Relationship between Microstructure and Properties of $1380 \mathrm{MPa}$ Grade Bainitic Rail Steel Treated by Online Bainite-Based Quenching and Partitioning Concept. Metals 2022, 12, 330. https://doi.org/10.3390/ met12020330

Academic Editor: Roumen Petrov

Received: 17 December 2021

Accepted: 8 February 2022

Published: 13 February 2022

Publisher's Note: MDPI stays neutral with regard to jurisdictional claims in published maps and institutional affiliations.

Copyright: (C) 2022 by the authors. Licensee MDPI, Basel, Switzerland. This article is an open access article distributed under the terms and conditions of the Creative Commons Attribution (CC BY) license (https:// creativecommons.org/licenses/by/ $4.0 /)$.

\begin{abstract}
According to the concept of the bainite-based quenching and partitioning (BQ\&P) process, we designed the online heat treatment routes of bainitic rail steel for heavy haul railway. The new heat treatment process reduced the fraction and size of the blocky martensite/austenite (M/A) islands formed during the conventional air-cooling process. The M/A islands are coarse and undesirable for mechanical properties. A new kind of $1380 \mathrm{MPa}$ grade bainitic rail steel with more uniform microstructure and better mechanical properties was produced by the online BQ\&P process. We characterized the multiphase microstructures containing bainite, martensite, and retained austenite of $1380 \mathrm{MPa}$ grade bainitic rail steels via optical microscope, scanning electron microscopy, transmission electron microscopy, and X-ray diffractometer. We investigated in-depth the relationship between the microstructure, retained austenite stability, and mechanical properties, particularly the resistance to wear and rolling contact fatigue, of the new $1380 \mathrm{MPa}$ grade bainitic rail steels. Meanwhile, the conventional air-cooling bainitic rail steel was studied as a comparison.
\end{abstract}

Keywords: bainitic rail steel; microstructure; retained austenite; wear; fatigue

\section{Introduction}

Railway transportation is one of the important modes of transportation in China, supporting the development of the national economy. Rail steel is the key component that affects the safety and efficiency of railway transportation. At present, high carbon pearlitic steels are used widely as rail material [1]. The development of high-speed and heavy-haul railways in China results in an increase in traffic density, train speed, and axle load. The current pearlitic rail steels are faced with more and more serious damage problems, such as wear, rolling contact fatigue (RCF), and catastrophic fracture [2]. The failure of pearlitic rail steels could threaten the safety of train operation and increase the maintenance cost of the railway. Therefore, it is necessary to develop a new generation of rail materials with excellent performance.

Compared with conventional pearlitic rail steels, low-alloyed bainitic rail steels have a better combination of strength and toughness, wear resistance, and RCF resistance [3-5]. In recent decades, many research institutions all over the world have been committed to the research and exploration of bainitic rail steels [3-10].

In the 1990s, Clayton et al. [3] studied the rolling contact fatigue of pearlitic and bainitic rail steels and pointed out the potential of bainitic steels for the railway. Bhadeshia et al. [4] reported new carbide-free bainitic rail steels with superior wear and RCF resistance. It is reported that the absence of brittle cementite particles contributed to the improved toughness and RCF resistance. Furthermore, the high toughness of the bainitic rail steels 
could improve wear resistance by reducing the generation of wear debris [4]. Yokoyama et al. [5] developed high-strength bainitic rail steels and found that the bainitic rail steels had at least twice the RCF resistance and almost equal wear resistance to those of the heat-treated pearlitic rail steels. The brittle white etching layer was difficult to form on the low carbon bainitic rail steels compared to high carbon pearlitic rail steels. Sawley and Kristan investigated the performance of a low carbon bainitic rail steel (i.e., J6 rail steel) via small- and full-scale tests [6]. They found that the RCF performance of bainitic rail steel appeared to be superior to that of pearlitic rail steel. Furthermore, the increased toughness of bainitic rail steel could increase the critical crack size before a sudden fracture. However, they also pointed out that the wear performance of bainitic rail steel exhibited mixed results from the small- and full-scale tests. Pacyna et al. [7] reported two grades of new bainitic steels with different head hardness, namely RB370 and RB390, where RB390 bainitic rail steel was designed for turnouts and railway frogs and was successfully used for heavy-haul lines. In contrast, Voestalpine Schienen developed a novel high carbon low-alloyed bainitic rail steel with high hardness up to $450 \mathrm{BHN}$, showing high resistance to the wear and RCF damage [8].

Recently, Kumar et al. $[9,10]$ designed a novel high-strength steel with a fine carbidefree bainitic microstructure for railway crossings applications. The mechanical properties of the newly designed bainitic steel were found to be superior to those of the conventional steels used in railway crossings. The bainitic steel offered controlled crack growth under impact fatigue, which is the main cause of failure in crossings. Hasan et al. [11] designed two new carbide-free bainitic rail steels with minimal alloying additions and processed them to achieve high strength and toughness for application in heavy-haul rail tracks. The results found that the carbide-free bainitic steels provided superior mechanical properties in comparison with the conventional $880 \mathrm{MPa}$ grade pearlitic rail steel and other bainitic steels of similar chemical composition.

Many works show that the strength and toughness, wear-resistance, and fatigue resistance of bainitic rail steels are higher than pearlitic rail steels [3-11]. In addition, bainitic rail steels also have excellent corrosion resistance. Moon et al. discussed [12] the corrosion behavior of newly developed bainitic steels made by isothermal heat treatment. They found that the modified chemical composition, finer microstructures, and compact rust morphology contributed to the better corrosion resistance of bainitic steels.

Since the 1990s, the bainitic rail steels have been developed rapidly in China. The relationships between the alloying, microstructure, process, and performance of bainitic rail steels have been investigated widely via in-lab small-scale and in-field full-scale tests [13-18]. The trial applications of bainitic rail steel on railway crossings and curved tracks have been carried out successfully. It has been found that bainitic rail steels show great potential in improving the service life of rail compared with heat-treated pearlite rails (340 370 HB).

The current bainitic rail steels are mostly produced via the process of natural air cooling plus low-temperature tempering after hot rolling. However, the cooling rate during natural air cooling varies with seasonal changes, resulting in the non-homogeneity in microstructure and performances of bainitic rail steels, especially the fluctuation of wear and RCF resistance [14]. Therefore, it is necessary to develop a new generation of online heat treatment processes for the bainitic rail, aiming to accurately control the microstructure and performances of bainitic rail steel. The optimization of the microstructure and mechanical properties via online heat treatment could, furthermore, improve the resistance to wear and fatigue and prolong the service life of bainitic rails.

In this study, we designed the online heat treatment routes of bainite rail steel for heavy haul railway according to the concept of the bainite-based quenching and partitioning (BQ\&P) process [19]. We investigated the microstructure, stability of retained austenite, and mechanical properties, particularly the resistance to wear and RCF, of the new bainitic rail steels. The conventional air cooling bainitic rail steel was also studied as a comparison. 


\section{Experimental Procedure}

The chemical composition of the bainitic rail steel is listed in Table 1 . The carbon content of the rail steel is much less than the pearlitic rail steels (generally, 0.7 0.9 wt.\%) [1,2]. The bainitic steel is melted, forged, and hot-rolled to rail at a steel mill.

Table 1. Chemical composition of the bainitic rail steel.

\begin{tabular}{ccccccc}
\hline Sample & C & Mn & Si & Cr & Ni & Mo \\
\hline Bainitic rail & 0.2 & 2.2 & 1.0 & 1.0 & 0.5 & 0.3 \\
\hline
\end{tabular}

Two different heat treatment processes are employed on the rail after hot rolling, namely the conventional naturally air-cooling process and online heat treatment based on the BQ\&P concept. The schematic of the microstructural evolution during the two heat treatment processes is shown in Figure 1. In general, vast heat is generated during the bainitic transformation, i.e., phase transformation latent heat. Hence, the rail is cooled at an extremely low cooling rate once the temperature is below the $B_{\mathrm{S}}\left(\sim 400{ }^{\circ} \mathrm{C}\right)$, where the bainitic transformation is triggered. The untransformed austenite could transform to martensite when the bainitic transformation is ceased and the temperature is below the $M_{\mathrm{s}}$ (martensitic transformation start temperature, $\sim 340{ }^{\circ} \mathrm{C}$ ). This process is also similar to the bainitic austempering process, as indicated in Figure 1a. In contrast, the online BQ\&P heat treatment is designed as follows, as indicated in Figure $1 \mathrm{~b}$. The railhead surface is cooled to a temperature below $M_{\mathrm{S}}\left(\sim 280^{\circ} \mathrm{C}\right)$ at an accelerated cooling rate of $\sim 4{ }^{\circ} \mathrm{C} / \mathrm{s}$ (via controlled spray cooling), but the cooling rate is lower than the critical quenching rate to form fully martensite. Hence, a part of parent austenite is transformed to bainite and martensite during the accelerated cooling step. Then, the accelerated cooling is stopped, which leads to the elevation of temperature on the railhead because of the presence of temperature gradient. The dynamic partitioning could take place during the final slow cooling step. The finite element simulation of the temperature change at the railhead can be found in our previous work [20]. Here, the bainitic rail steels treated by the conventional natural air cooling and online BQ\&P processes are called $1280 \mathrm{G}$ and $1380 \mathrm{G}$ rail steel, respectively. Finally, both $1280 \mathrm{G}$ and $1380 \mathrm{G}$ rail steels are tempered at $280{ }^{\circ} \mathrm{C}$.
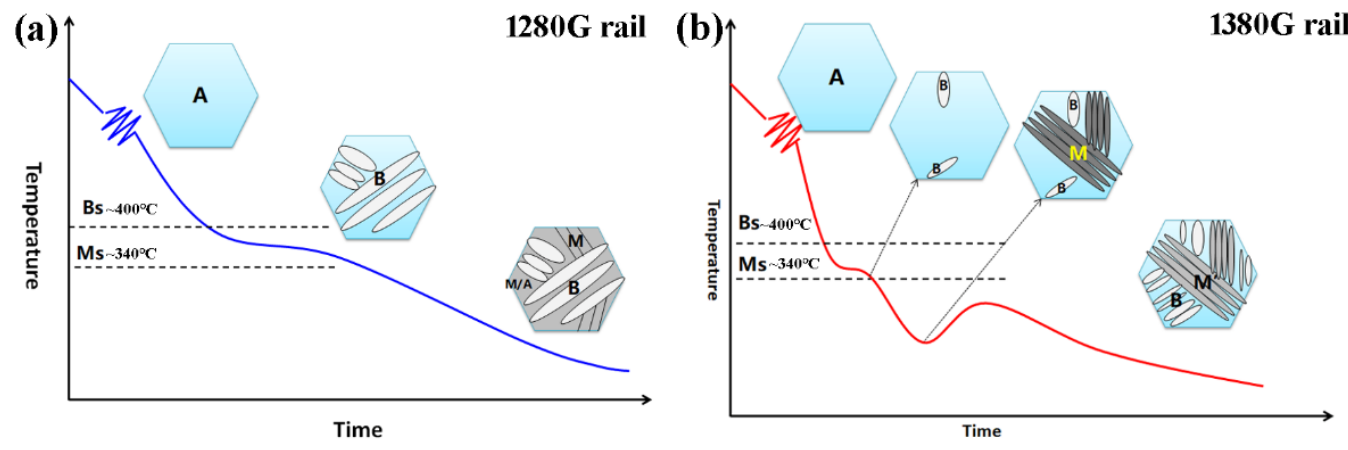

Figure 1. Schematic of the microstructural evolution of bainitic rail steels during natural air-cooling process and on-line heat treatment based on BQ\&P concept. (a) Air-cooling process for $1280 \mathrm{G}$ rail steel; (b) on-line BQ\&P for $1380 \mathrm{G}$ rail steel; A: austenite, B: bainite, M: martensite.

The specimens for microstructural characterization were cut from a depth of $10 \mathrm{~mm}$ from the railhead surface. The microstructure was characterized by optical microscopy (OM, Zeiss Scope.A1) and scanning electron microscopy (SEM, Zeiss EVO18, 20 kV) after mechanical polishing and etching in a $2 \%$ nital solution. The ultrafine retained austenite or carbide was investigated by a field emission transmission electron microscope (TEM, JEOL $2010 \mathrm{~F}, 200 \mathrm{kV}$ ) using the thin foil samples electrolytically polished at $-40{ }^{\circ} \mathrm{C}$ in $4 \%$ perchloric acid solution. The volume fraction and lattice parameter of retained austenite were estimated by X-ray diffractometer (XRD, Rigaku Smartlab, $\mathrm{Cu} \mathrm{K} \alpha$ radiation) at a step 
of $0.01^{\circ}$ and a counting time of $2 \mathrm{~s} /$ step over the $2 \theta$ range of $35-95^{\circ}$. The specimens used for XRD measurement were prepared by mechanical grinding and electrolytic polishing in order to remove the deformed layer near the specimen surface. The retained austenite fraction was estimated by collecting the peak intensities of $(200)_{\gamma},(220)_{\gamma},(311)_{\gamma},(200)_{\alpha}$, and $(211)_{\alpha}$. The austenite lattice parameter, $\mathrm{a}_{\gamma}$, was obtained by Nelson-Riley extrapolation method. The carbon concentration, $x_{C}$, of retained austenite can be estimated using Equation (1) [21]:

$$
\mathrm{a}_{\gamma}=3.556+0.0453 x_{\mathrm{C}}^{\gamma}+0.00095 x_{\mathrm{Mn}}^{\gamma}+0.0056 x_{\mathrm{Al}}^{\gamma}
$$

where the austenite lattice parameter, $\mathrm{a}_{\gamma}$, is in $\AA$, and $x_{\mathrm{C}}^{\gamma}, x_{\mathrm{Mn}}^{\gamma}$, and $x_{\mathrm{Al}}^{\gamma}$ are the concentrations of carbon, manganese, and aluminum in austenite, respectively, in wt.\%.

The specimens for the mechanical properties test (including tensile, U-notch impact, and fracture toughness tests) were prepared according to the standard of TB/T2344-2012. Three specimens were tested for each condition and the average values were recorded. In order to investigate the mechanical stability of retained austenite, the interrupted tensile test was carried out, and the change of retained austenite fraction as engineering strain was measured.

The wear test was carried out under dry wear conditions on the GPM-30D twin-disc wear testing machine (Yihua, China), as shown in Figure 2. The rail specimens for upper discs were cut from the depth of $0 \sim 20 \mathrm{~mm}$ from the railhead surface. The wheel specimens as lower discs pair were CL70 pearlitic wheel steel treated by normalizing. The CL 70 pearlitic wheel steel has a carbon content of $\sim 0.7 \mathrm{wt} . \%$ and has been used in the freight train. The mechanical properties of CL70 steel can be found in Ref [22]. Both the rail and wheel disc specimens have the same outer diameter $(60 \mathrm{~mm})$. The other dimensions of the disc specimens can be found in Ref [23]. The twin-disc specimens were contacted in a line during the wear test. In this study, the rotational speed of the rail disc was set to $500 \mathrm{rpm}$, while that of the wheel disc was set to $497 \mathrm{rpm}$. In this case, the slip ratio is about $0.6 \%$, as calculated by the methods in Ref [23]. It is reported that the nominal contact stress is $\sim 650 \mathrm{MPa}$ when the train load is 23 tons $[17,24]$. However, the maximum contact stress can exceed the nominal value during serious operation. Hence, in this study, the load of $2000 \mathrm{~N}$ was applied to the disc specimens, which generated a maximum Hertzian contact pressure of $\sim 980 \mathrm{MPa}$. In order to investigate the RCF cracks initiation and propagation during cyclic contact, the rolling cyclic numbers were set to $1 \times 10^{5}, 2.5 \times 10^{5}, 5 \times 10^{5}$, and $7.5 \times 10^{5}$ cycles, respectively.

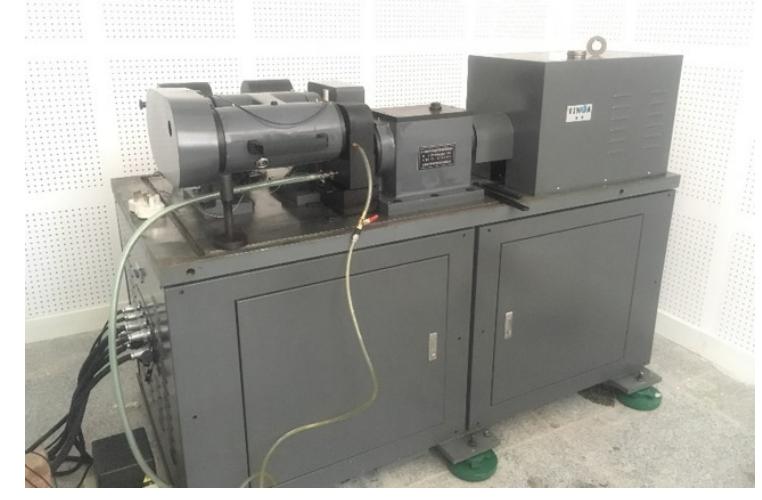

Figure 2. Photograph of the GPM-30D twin-disc wear testing machine.

After the wear test, the wear mass loss was measured using an electronic scale with a resolution accuracy of $0.0001 \mathrm{~g}$. The worn surface of rail specimens was characterized using SEM (Zeiss EVO18, $20 \mathrm{kV}$ ). The longitudinal-section samples were cut along the rolling direction and etched in $2 \%$ nital solution after mechanical polishing. The distribution of hardness of the samples was measured by a Vickers hardness tester (HVS-1000) under a 
load of $25 \mathrm{gf}$ and a dwell time of $10 \mathrm{~s}$. The relationship between microstructure, plastic deformation, and micro-cracks was investigated using SEM (Zeiss EVO18, $20 \mathrm{kV}$ ).

\section{Results and Discussion}

\subsection{Microstructure}

Figure 3 shows the OM and SEM images of the $1280 \mathrm{G}$ and $1380 \mathrm{G}$ microstructures at the depth of $10 \mathrm{~mm}$ from the railhead surface. The OM image in Figure 3a shows that there are banded structures in the $1280 \mathrm{G}$ samples, which is attributed to the microsegregations of $\mathrm{Mn}, \mathrm{Si}, \mathrm{Cr}$, etc., in the steel, as discussed in Ref [17]. However, the banded structures are not found in the $1380 \mathrm{G}$ samples after online BQ\&P treatment, as shown in Figure 3c. Forouzan et al. also reported that the Q\&P process could minimize the microsegregation induced banded structures via controlling the quenching temperature [25]. The bainite in the $1280 \mathrm{G}$ sample is mainly granular bainite, as shown in Figure $3 \mathrm{~b}$. The granular bainite consists of coarse bainitic ferrite, $\mathrm{M}$ /A constituent, and film-like retained austenite. As indicated in Figure $3 \mathrm{~d}$, the microstructure of the $1380 \mathrm{G}$ rail steel is also a multiphase of bainite and martensite. However, the bainite in the $1380 \mathrm{G}$ samples exhibits lath or leaf morphologies, with smaller sheaf sizes. The accelerated cooling could reduce the transformation temperature, which leads to the bainitic transformation at a lower temperature range and subsequent refined bainitic microstructure. The martensite formed during the accelerated cooling step could provide the carbon atoms to the adjacent untransformed austenite during the dynamic partitioning [26]. The carbon partitioning from martensite to austenite could result in the formation of "carbon-depleted martensite" and carbon-enriched retained austenite [27].
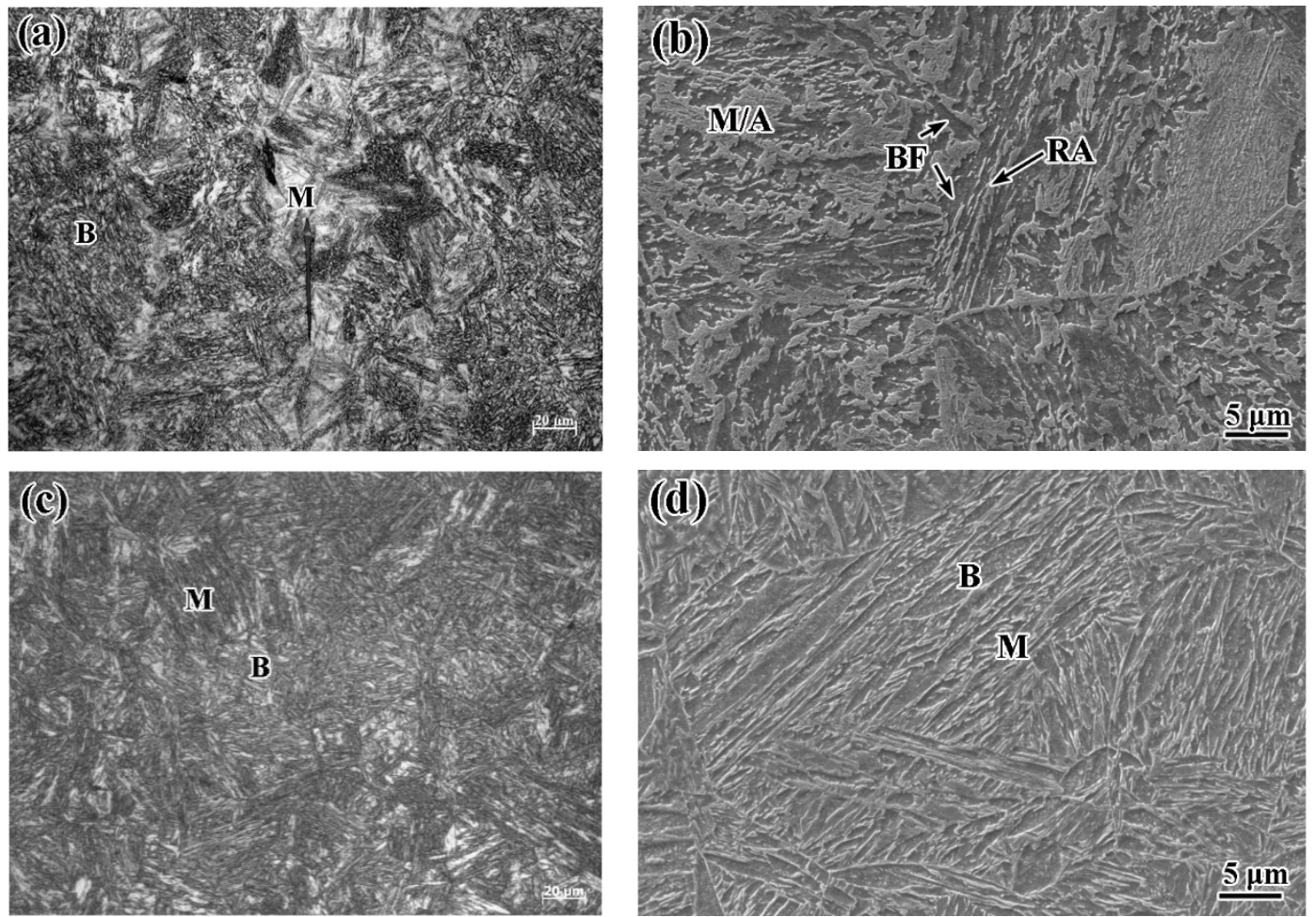

Figure 3. Microstructure of $1280 \mathrm{G}$ and $1380 \mathrm{G}$ rail steels. (a,b) 1280G; (c,d) 1380G; (a,c) OM images; (b,d) SEM images; B: bainite, M: martensite, BF: bainitic ferrite, M/A: martensite/austenite, RA: retained austenite.

Figure 4 shows the TEM images of the $1280 \mathrm{G}$ and $1380 \mathrm{G}$ microstructures at the depth of $10 \mathrm{~mm}$ from the railhead surface. It is found that the width of the bainite lath in the 1280 $\mathrm{G}$ sample is approximately $2 \mu \mathrm{m}$. In contrast, the width of the bainite lath in the $1380 \mathrm{G}$ 
sample is a sub-micron meter. Meanwhile, the film-like retained austenite can be found between the bainite laths.
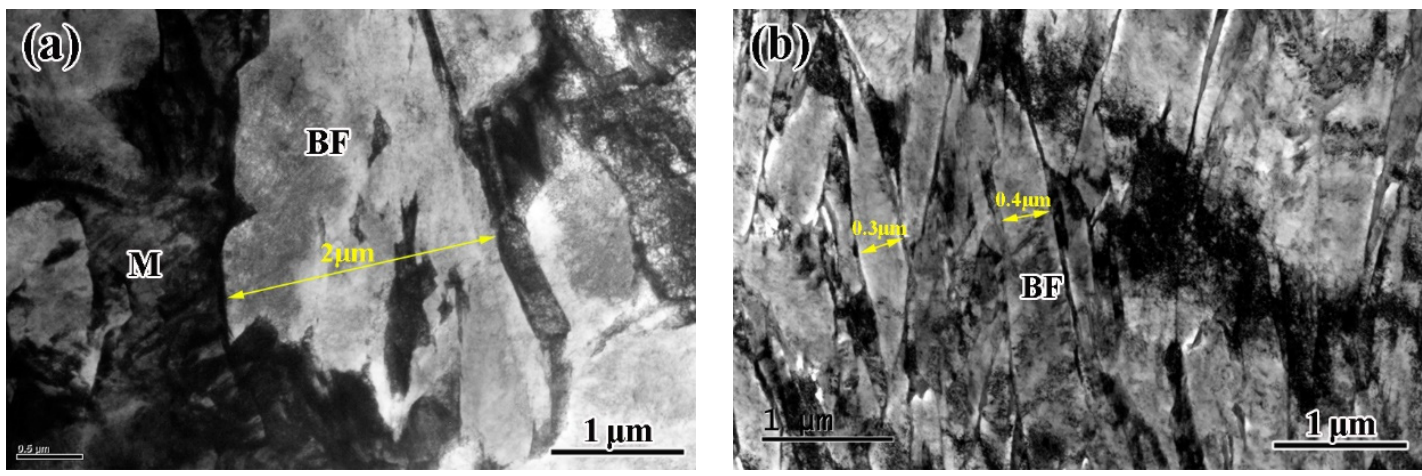

Figure 4. TEM images of the microstructure of $1280 \mathrm{G}$ and $1380 \mathrm{G}$ rail steels. (a) 1280G; (b) 1380G; BF: bainite ferrite, M: martensite.

In order to investigate in detail the constitutes of bainite and martensite in $1380 \mathrm{G}$ rail steel, the TEM analysis was carried out, as indicated in Figure 5. It is found that the microstructure of the $1380 \mathrm{G}$ rail steel is more complex. The multiphase structure is considered to be beneficial to the mechanical properties. The bainite mainly exhibits lath morphology with the presence of inter-lath film-like retained austenite, as shown in Figure $5 a, b$. The width of retained austenite is tens of nanometers. As indicated in Figure $5 c, d$, the lower bainite is also observed in the $1380 \mathrm{G}$ bainitic rail steel. The carbide is distributed within the bainitic plates and located along a certain angle. Meanwhile, carbon-depleted martensite is found in the $1380 \mathrm{G}$ steel. The martensite has a straighter lath boundary and smaller lath width, compared with bainite, as shown in Figure 5e. Furthermore, the film-like retained austenite can be found between the carbon-depleted martensite laths, which can be attributed to the carbon partitioning from martensite to the untransformed austenite during the dynamic partitioning process [26,27].

\subsection{Mechanical Stability of Retained Austenite}

It is reported that the retained austenite with appropriate stability is beneficial to the ductility, toughness, and fatigue of high-strength steels [28,29]. Hence, we compared the stability of retained austenite in the $1280 \mathrm{G}$ and $1380 \mathrm{G}$ rail steels in this section. Table 2 lists the retained austenite amount and its carbon content in the $1280 \mathrm{G}$ and $1380 \mathrm{G}$ rail steels. It is found that the volume fraction of retained austenite is $\sim 7.5 \%$ in the untempered $1280 \mathrm{G}$ steel. The presence of retained austenite is attributed to the carbon enrichment in untransformed austenite during bainitic transformation. The retained austenite amount decreases to $\sim 5.6 \%$ in the tempered $1280 \mathrm{G}$ steel. In contrast, the retained austenite amount is $\sim 6.6 \%$ and $\sim 4.9 \%$ for the untempered and tempered 1380 steel, respectively. The carbon content in RA in the $1380 \mathrm{G}$ steel is slightly lower compared with the $1280 \mathrm{G}$ steel. It may be attributed to the formation of carbide during the dynamic partitioning process, which is considered as the competition process of carbon enrichment in retained austenite [30]. 

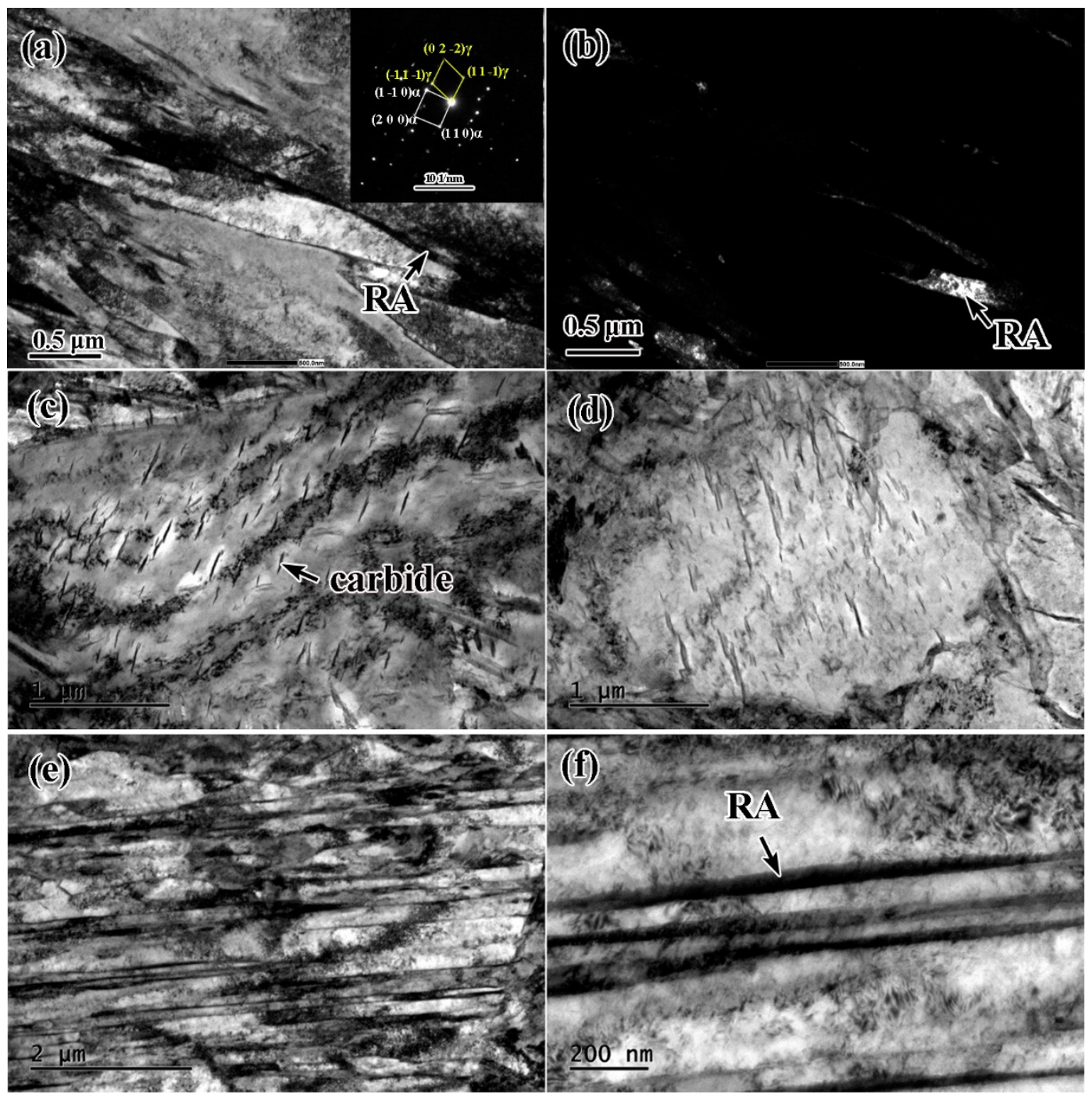

Figure 5. TEM images of microstructure in $1380 \mathrm{G}$ rail steels. (a) bright field image showing lath bainite with inter-lath film-like retained austenite, where the inset image is the selected area electron diffraction patterns; (b) dark field image showing retained austenite; $(\mathbf{c}, \mathbf{d})$ carbide in lower bainite; $(\mathbf{e}, \mathbf{f})$ martensite lath and inter-lath film-like retained austenite.

Table 2. Retained austenite amount (RA \%) and its carbon content (C \%) in the $1280 \mathrm{G}$ and $1380 \mathrm{G}$ rail steels before or after tempering, determined by $\mathrm{X}$-ray diffraction.

\begin{tabular}{ccccc}
\hline Sample & $\begin{array}{c}\text { RA \% } \\
\text { (Untempered) }\end{array}$ & $\begin{array}{c}\text { C \% in RA } \\
\text { (Untempered) }\end{array}$ & $\begin{array}{c}\text { RA \% } \\
\text { (Tempered) }\end{array}$ & $\begin{array}{c}\text { C \% in RA } \\
\text { (Tempered) }\end{array}$ \\
\hline $1280 \mathrm{G}$ & $7.5 \mathrm{vol} . \%$ & $1.34 \mathrm{wt} . \%$ & $5.6 \%$ & $1.39 \%$ \\
$1380 \mathrm{G}$ & $6.6 \mathrm{vol.} \%$ & $1.14 \mathrm{wt} . \%$ & $4.9 \%$ & $1.17 \%$ \\
\hline
\end{tabular}

In order to compare the mechanical stability of the retained austenite in the two rail steels, we carried out the interrupted tensile test and measured the volume fraction of retained austenite after subjecting different strains. Figure 6 shows the change of retained austenite amount versus the engineering strain for the $1280 \mathrm{G}$ and $1380 \mathrm{G}$ rail steels. It is found that the retained austenite amount decreases gradually with the true strain for all the samples. The relation between the fraction of retained austenite and the true strain, $\varepsilon$, can be presented by the exponent decay law $[19,31]$ :

$$
f=f_{0} \exp (-k * \varepsilon)
$$


where $k$ is the constant, revealing the overall mechanical stability of retained austenite during deformation. A lower $k$ indicates the higher mechanical stability of retained austenite. The fitting lines are shown in Figure 6 as well. It is found that the mechanical stability of retained austenite shows improvement in the tempered $1280 \mathrm{G}$ steel. The retained austenite in the $1380 \mathrm{G}$ steel shows high stability even in the untempered state, which is comparable to the tempered $1280 \mathrm{G}$ steel. The stability of retained austenite could be further improved in the $1380 \mathrm{G}$ steel after tempering. As indicated in Figures 4 and 5, the retained austenite mostly exhibits film-like morphology and has a smaller size in $1380 \mathrm{G}$ steel compared with the coarse blocky M/A in $1280 \mathrm{G}$ steel. Hence, the retained austenite in the $1380 \mathrm{G}$ steel has better mechanical stability despite lower carbon content in retained austenite.

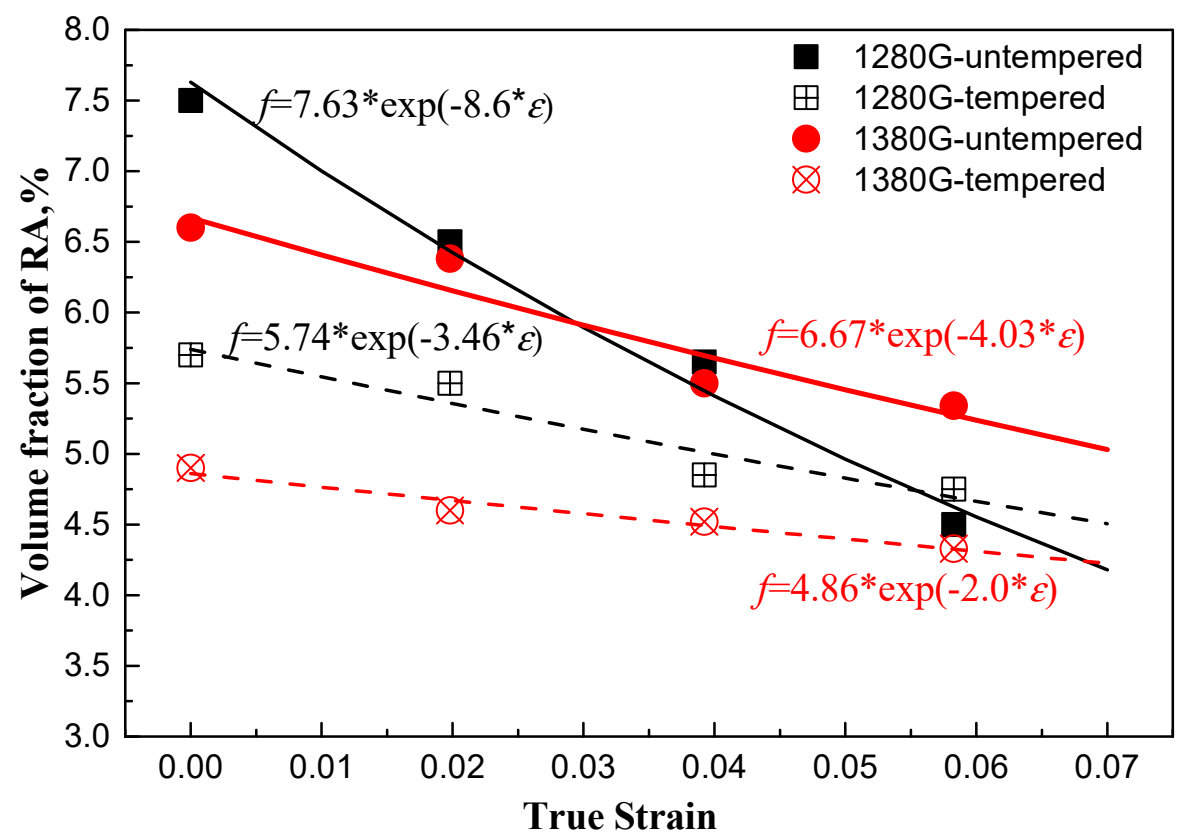

Figure 6. Change of retained austenite amount with engineering strain for $1280 \mathrm{G}$ and $1380 \mathrm{G}$ rail steels. Note: the errors of all the results obtained by XRD are within $\pm 5 \%$.

\subsection{Mechanical Properties}

Table 3 lists a comparison of the conventional mechanical properties of the tempered $1280 \mathrm{G}$ and $1380 \mathrm{G}$ rail steels. It is found that the $1380 \mathrm{G}$ steel has higher strength and toughness compared to the $1280 \mathrm{G}$ steel. The tensile strength of the $1380 \mathrm{G}$ steel is above $1380 \mathrm{MPa}$ and has an elongation of $\sim 15 \%$, showing an excellent balance of strength and ductility. Furthermore, the fracture toughness of the $1380 \mathrm{G}$ steel is significantly improved. The increased toughness could increase the critical crack size before a sudden fracture and ensure the safety of train operation [4]. The improved strength and toughness are attributed to the refined microstructure and high stability of the retained austenite in the $1380 \mathrm{G}$ rail steel.

Table 3. Strength and toughness of the $1280 \mathrm{G}$ and $1380 \mathrm{G}$ rail steels.

\begin{tabular}{cccccc}
\hline Sample & $\mathbf{R}_{\mathbf{m}}, \mathbf{M P a}$ & $\mathbf{R}_{\mathbf{p}}, \mathbf{M P a}$ & $\mathbf{A}, \mathbf{\%}$ & $\mathbf{A}_{\mathbf{K U}}, \mathbf{J}$ & $\mathbf{K}_{\mathbf{I C}} \mathbf{a t}-\mathbf{2 0}{ }^{\circ} \mathbf{C}, \mathbf{M P a} \cdot \mathbf{m}^{\mathbf{1 / 2}}$ \\
\hline $1280 \mathrm{G}$ & $1335 \pm 8$ & $1208 \pm 12$ & $14.5 \pm 0.5$ & $79 \pm 2$ & $77 \pm 12$ \\
$1380 \mathrm{G}$ & $1390 \pm 5$ & $1263 \pm 10$ & $15.0 \pm 0.5$ & $104 \pm 1$ & $107 \pm 4$ \\
\hline
\end{tabular}

$R_{m}$ : tensile strength, $R_{p}$ : yield strength, A: elongation, $A_{K U}: U$-notched impact toughness, $K_{I C}$ : fracture toughness.

\subsection{Wear Resistance of Bainitic Rail Steel}

The wear resistance of the $1280 \mathrm{G}$ and $1380 \mathrm{G}$ bainitic rail steels is compared through a twin-disc wear testing machine. Figure 7 shows the wear mass loss of two bainitic rail 
steels with rolling cycles. It can be seen that the wear resistance of the $1380 \mathrm{G}$ rail steel is much better than the $1280 \mathrm{G}$ variant, especially at the late stage of wear. For instance, the wear mass loss of the $1280 \mathrm{G}$ steel $(\sim 1.03 \mathrm{~g})$ is almost twice that of the $1380 \mathrm{G}$ steel $(\sim 0.59 \mathrm{~g})$ when the cyclic number reaches $7.5 \times 10^{5}$.

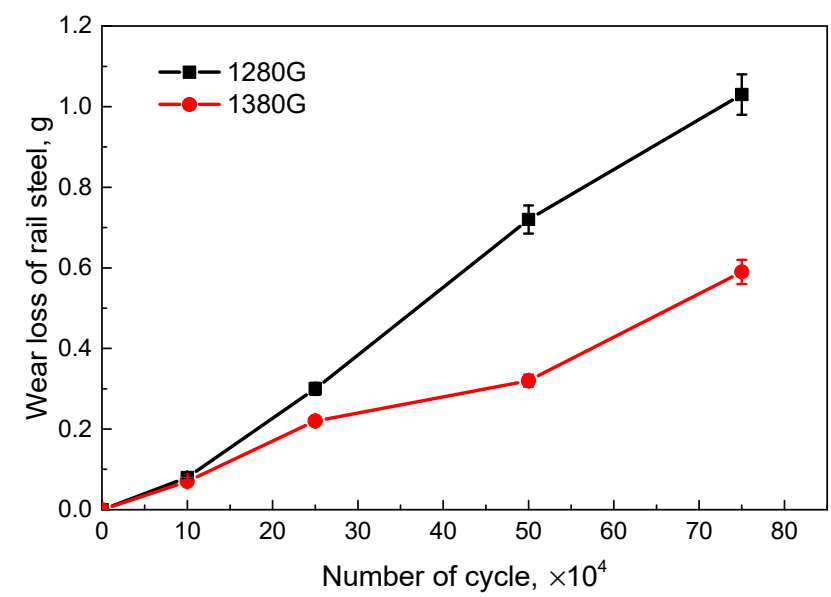

Figure 7. Change of wear mass loss of $1280 \mathrm{G}$ and $1380 \mathrm{G}$ rail steels with rolling cycles.

The worn surfaces of the $1280 \mathrm{G}$ bainitic rail steel after different rolling cycles are shown in Figure 8. The worn surfaces exhibit typical fatigue wear characteristics at the early stage. The large contact and shear stress cause severe plastic deformation, which promotes the preferential formation of parallel fatigue cracks on the sample surface [32]. Moreover, the cracks could grow to the subsurface layer with the increase in rolling cycles. After $1.0 \times 10^{5}$ cycles, the worn surface exhibits a large number of micro-cracks or peelings, as shown in Figure $8 \mathrm{a}, \mathrm{b}$. The cracks and peelings tend to be arrayed after $2.5 \times 10^{5}$ cycles. The parallel micro-cracks distribute at intervals, and the size appears to be larger (Figure 8c,d). The number of micro-cracks and peelings decreases after $5.0 \times 10^{5}$ cycles (Figure 8e,f). However, the micro-cracks start to connect with each other, which promotes peeling. Consequently, the wear debris is found on the worn surface as the rolling cyclic numbers increased to $7.5 \times 10^{5}$ (Figure $8 \mathrm{~g}$, h). In this case, the wear mechanism will dominate the wear loss of rail steels without severe fatigue cracking.

Figure 9 shows the worn surface of the $1380 \mathrm{G}$ bainitic rail steel under different rolling cycles. After $1.0 \times 10^{5}$ cycles, a small number of micro-cracks and peelings are also observed on the worn surface (Figure 9a). The number of micro-cracks and peelings decreases obviously when the cycles exceed $2.5 \times 10^{5}$ (Figure 9b-d). This indicates that the wear mechanism will dominate the wear loss of rail steels with the increased cyclic numbers, which is similar to the $1280 \mathrm{G}$ rail steel. Meanwhile, it is found that the number of micro-cracks is much less in the $1380 \mathrm{G}$ rail steel compared with the $1280 \mathrm{G}$ rail steel. In other words, the $1380 \mathrm{G}$ rail steel has a higher resistance to fatigue crack initiation compared with the $1280 \mathrm{G}$ rail steel.

The hardness distributions from the worn surface to the substrate of two bainitic rail steels are shown in Figure 10. It can be seen that the hardness gradually decreases and finally plateaus with the increase in depth. The increased hardness at the top surface is mainly attributed to the plastic deformation under the contact of the rail and wheel, as indicated in Figure 11. Hence, we also find the depth of the plastic deformation layer from the hardness distribution. The depth of the plastic deformation layer of the $1280 \mathrm{G}$ rail steel is $\sim 80 \mu \mathrm{m}$ at the $1.0 \times 10^{5}$ cycles and $2.5 \times 10^{5}$ cycles and increases to more than $100 \mu \mathrm{m}$ as the cycles increase to above $5.0 \times 10^{5}$ cycles. In contrast, the depths of the plastic deformation layers are all at the range of $50 \mu \mathrm{m}$ to $60 \mu \mathrm{m}$ for the $1380 \mathrm{G}$ rail steel. The depth of the plastic deformation layer reflects the resistance to the plastic deformation of the microstructure. It can be seen that the $1380 \mathrm{G}$ rail steel exhibits higher resistance to plastic deformation under wheel/rail contact compared with the $1280 \mathrm{G}$ rail steel. 

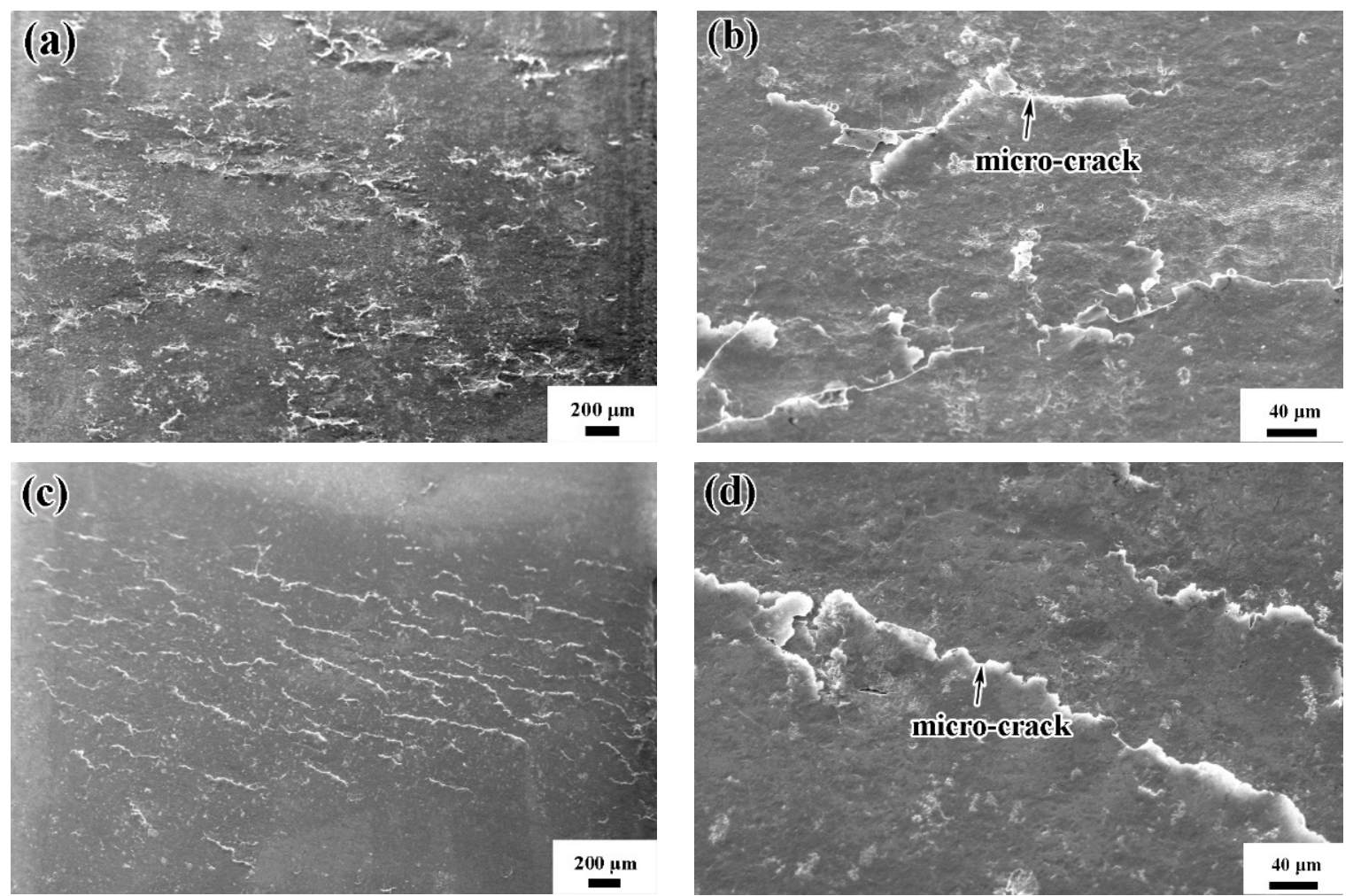

(e)
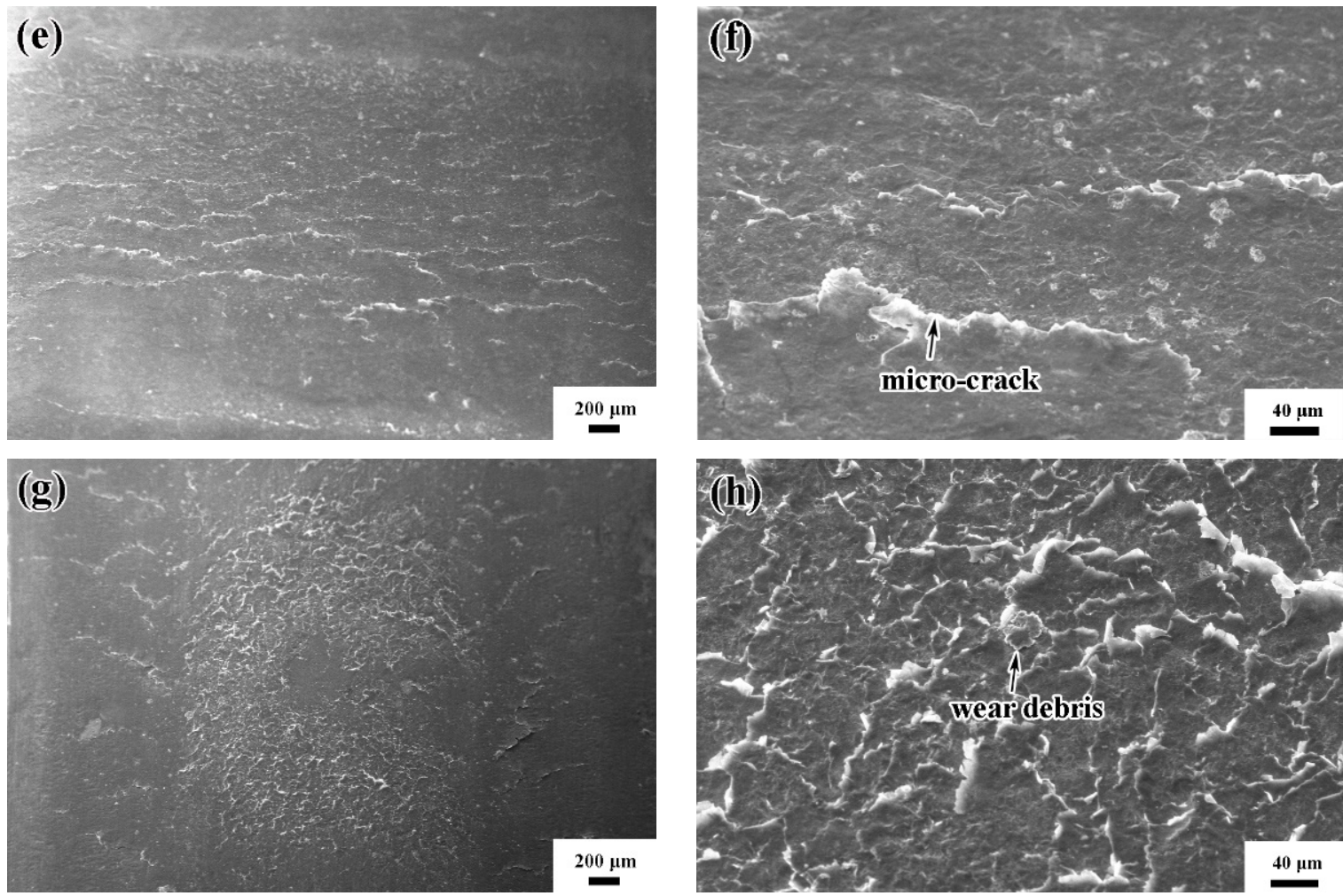

Figure 8. Worn surface of $1280 \mathrm{G}$ rail steel under different rolling cycles. (a,b) $1.0 \times 10^{5}$ cycles; (c,d) $2.5 \times 10^{5}$ cycles; $(\mathbf{e}, \mathbf{f}) 5.0 \times 10^{5}$ cycles; $\left(\mathbf{g}\right.$,h) $7.5 \times 10^{5}$ cycles. 

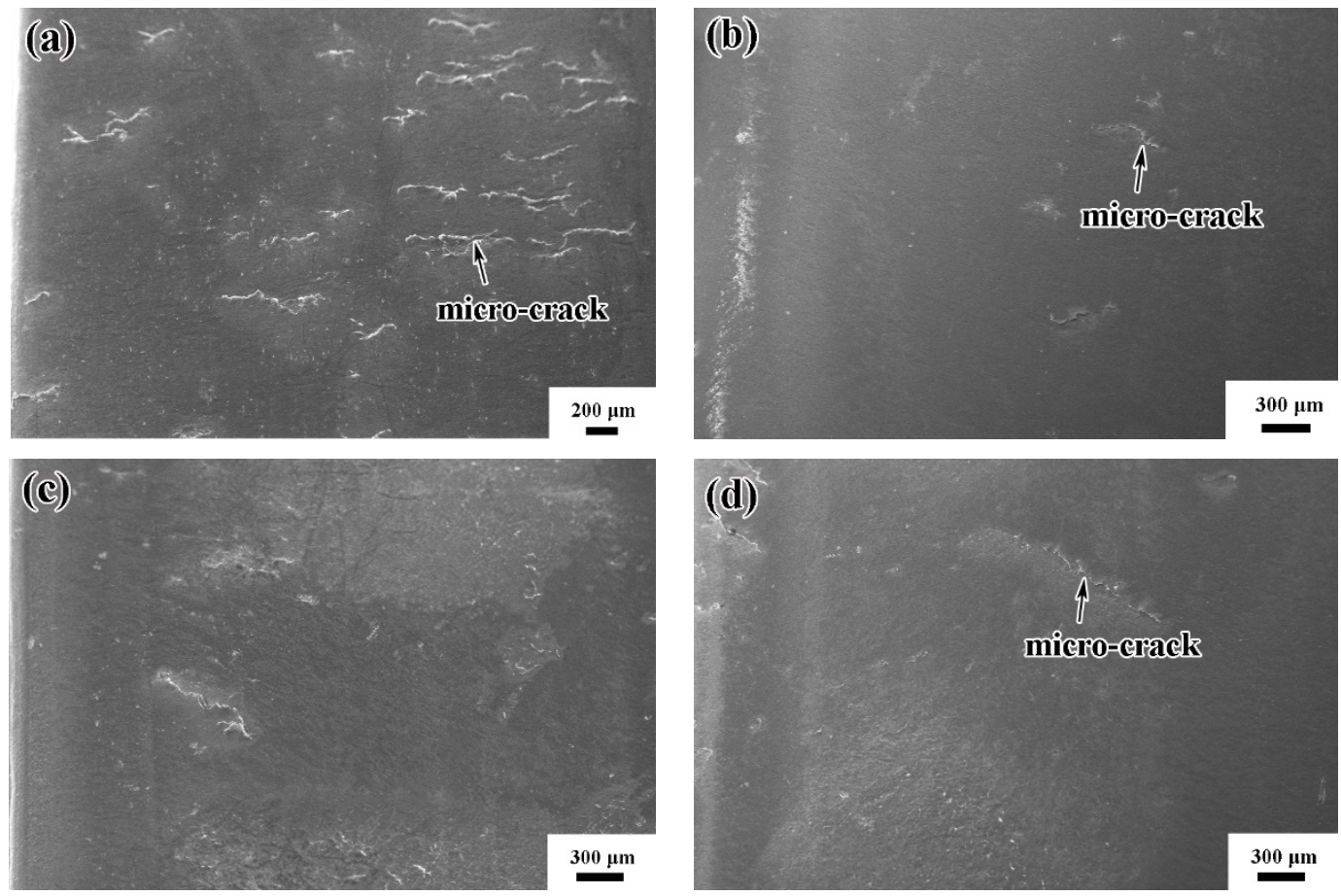

Figure 9. Worn surface of $1380 \mathrm{G}$ rail steel under different rolling cycles. (a) $1.0 \times 10^{5}$ cycles; (b) $2.5 \times 10^{5}$ cycles; (c) $5.0 \times 10^{5}$ cycles; (d) $7.5 \times 10^{5}$ cycles.
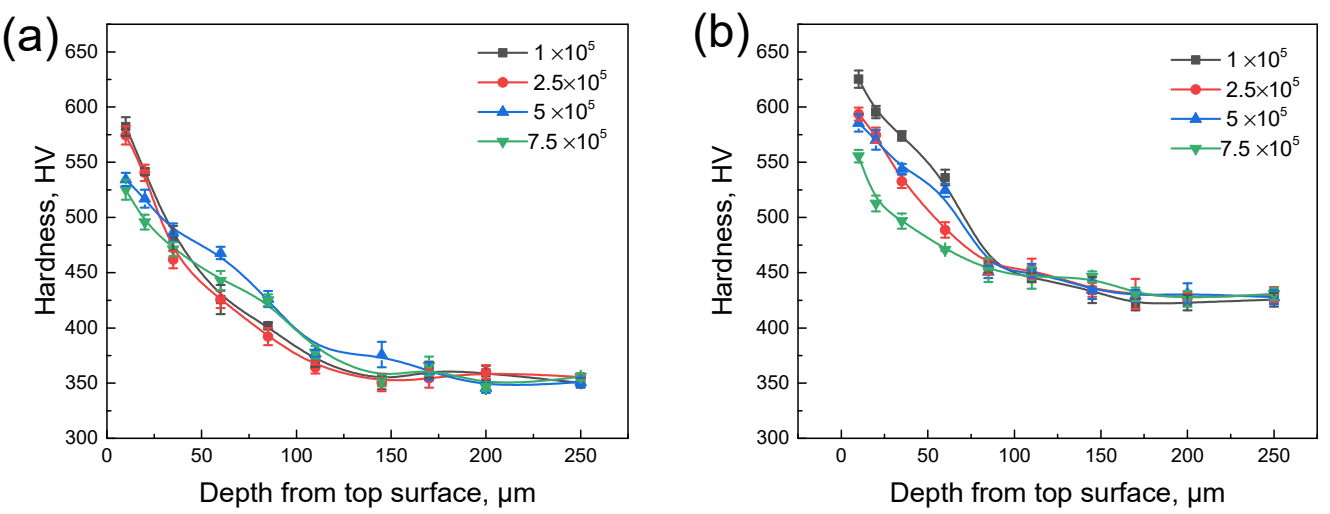

Figure 10. Hardness distribution of worn samples with the depth from top surface. (a) $1280 \mathrm{G}$ rail steel; (b) $1380 \mathrm{G}$ rail steel.

Meanwhile, it is found that, for the two kinds of rail steels, the hardness of the surface layer is higher at the early stage of the wear stage but decreases slightly with the increase in cycles. This may be attributed to the tempering of the top surface layer caused by the temperature rise during the wheel/rail contact [33].

Figure 11 shows the microstructure of the longitudinal section of the $1280 \mathrm{G}$ and 1380 $\mathrm{G}$ rail steels after different rolling cycles. It is found that the microstructure is elongated or fragmented near the contact surface due to the plastic deformation, as shown by the SEM images in Figure 11. This also confirms that the depth of the plastic deformation layer is larger in the $1280 \mathrm{G}$ rail steel compared to the $1380 \mathrm{G}$ rail steel. The micro-cracks are prone to initiate at the surface and grow to the sub-surface in the $1280 \mathrm{G}$ rail steel (Figure 11a). The cracks change the propagation path with the increase in rolling cycles, as indicated in Figure 11b, which could lead to the peeling. In contrast, the micro-cracks are rarely found in the $1380 \mathrm{G}$ samples. This is also consistent with the results in Figures 8 and 9. Meanwhile, we can see that the plastic deformation is not uniform in the $1280 \mathrm{G}$ worn samples, as indicated by the yellow dashed lines in Figure 11b. This is attributed 
to the segregation banded structure in the parent microstructure of the $1280 \mathrm{G}$ rail steel (as shown in Figure 3a). Recently, Zhang et al. [17] reported that the cracks propagated along with the segregation band under cyclic load, so segregation promoted the initiation and propagation of fatigue cracks and reduced the service life of the rail. Compared with the $1280 \mathrm{G}$ rail steel, the microstructure in the $1380 \mathrm{G}$ rail steel is more homogeneous and refined (Figure 3c,d), which could suppress the fatigue crack initiation during wheel/rail rolling contact.
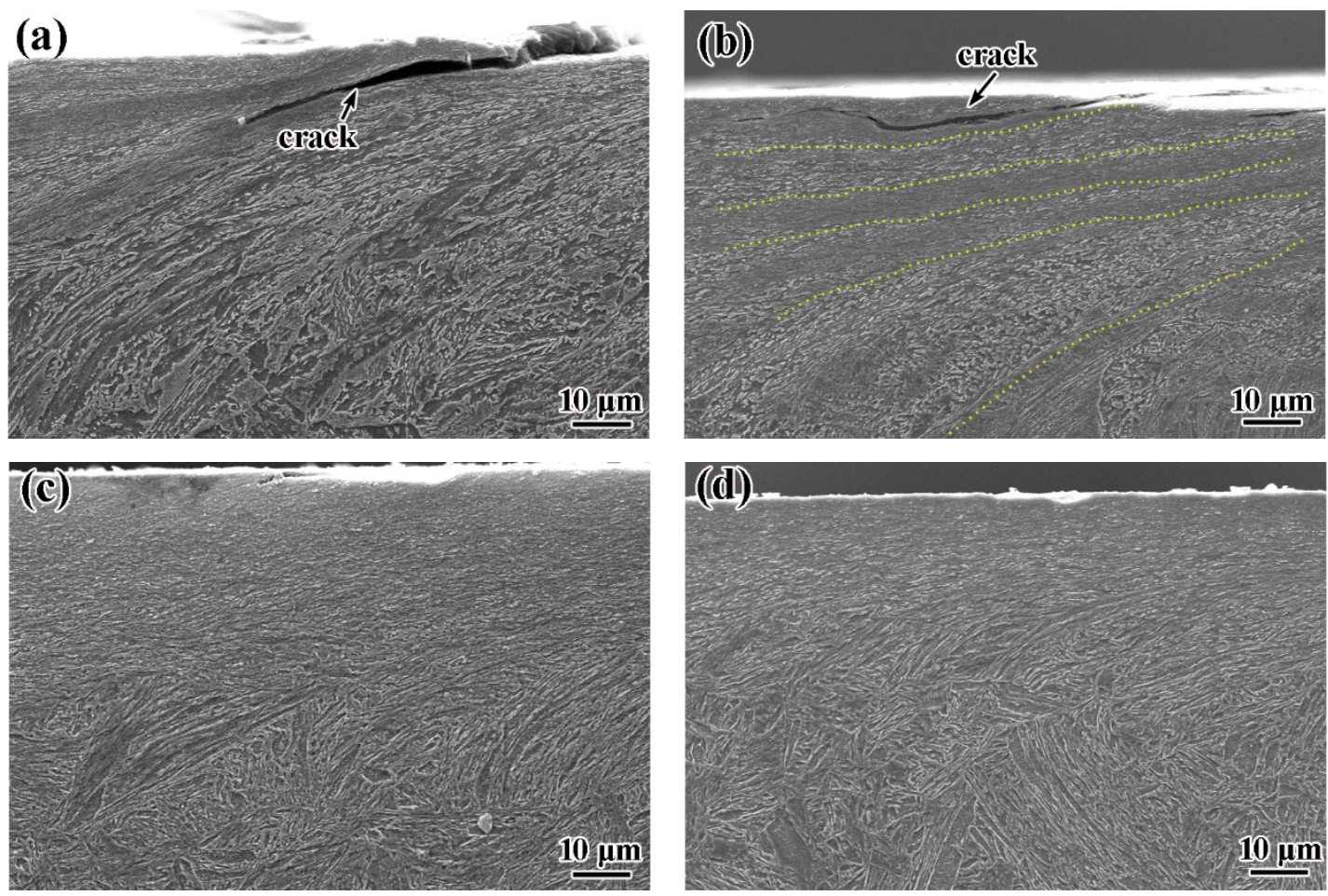

Figure 11. Microstructure of the longitudinal section of the $1280 \mathrm{G}$ and $1380 \mathrm{G}$ rail steels under different rolling cycles. (a) $1280 \mathrm{G}$ after $1 \times 10^{4}$ cycles; (b) $1280 \mathrm{G}$ after $7.5 \times 10^{4}$ cycles, where yellow dashed lines show the uneven deformation of segregation bands; (c) $1380 \mathrm{G}$ after $1 \times 10^{4}$ cycles; (d) $1380 \mathrm{G}$ after $7.5 \times 10^{4}$ cycles.

In summary, the $1380 \mathrm{G}$ bainitic rail steel has superior resistance to plastic deformation and fatigue crack initiation, so it exhibits better wear resistance compared with the $1280 \mathrm{G}$ rail steel. In general, it is considered that the higher hardness of pearlitic rail could result in the shallow plastic deformation layer, but its crack propagation is more significant, and the fatigue damage is more severe. Hence, the rolling contact fatigue (RCF) damage is always serious in the case of mild wear [34]. However, in this study, we found that the resistance to plastic deformation and crack initiation is improved simultaneously, which leads to the lower density of micro-cracks and thinner plastic deformation layer in $1380 \mathrm{G}$ rail steel. In this case, the spalling and peeling are rarely formed, which reduced the wear loss mass in the $1380 \mathrm{G}$ rail steel. It is suggested that the fine multiphase structure and high stable retained austenite contribute to the improvement of wear and RCF of the $1380 \mathrm{G}$ bainitic rail steel.

Meanwhile, the online heat treated bainitic rail steels have been used at the curved track of heavy haul railway. Figure 12 shows the profile of the $1380 \mathrm{G}$ worn rail steel after experiencing $~ 500$ MGT (million gross tons). It is found that the most severe position of worn rails has a maximum side wear of $\sim 5.5 \mathrm{~mm}$ and vertical wear of $\sim 3.8 \mathrm{~mm}$. Meanwhile, the spalling and peeling are not found on the worn rail surface. 


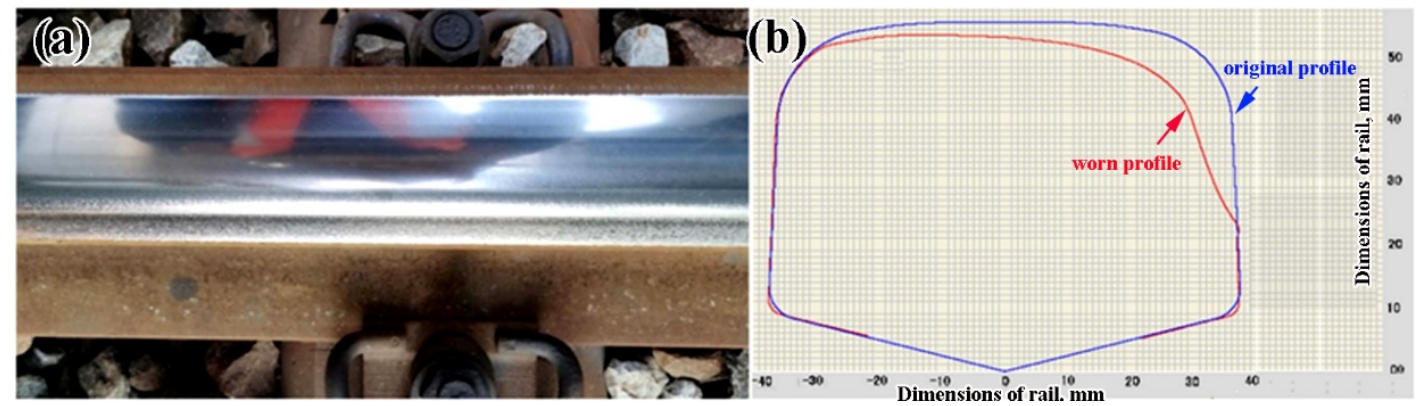

Figure 12. (a) Photograph of a $1380 \mathrm{G}$ bainitic rail steel after the experience of $\sim 500$ million gross tons at the curved track of heavy haul railway; (b) the cross-section profile, where the blue and red lines show the original and worn profiles, respectively.

Based on the operation report of the railway, the current pearlitic rail steel (HB330 grade) would be worn to the limit (maximum side wear of $\sim 15 \mathrm{~mm}$ ) after the passing gross load of 500 MGT. However, it is speculated that the $1380 \mathrm{G}$ bainitic rail steel could endure the passing gross load of more than 1000 MGT according to the change of cross-section profile (Figure 12b). The rail grinding is not necessary during the service of $1380 \mathrm{G}$ bainitic rail steels since there is not any serious contact surface damage, which would save a great deal of maintenance costs. Hence, although there is a high alloying cost, the life cycle cost (LCC) of $1380 \mathrm{G}$ bainitic rail steels could be reduced by about $50 \%$ compared with the conventional pearlitic rail steels. Furthermore, it is also most important that the $1380 \mathrm{G}$ bainitic rail steels have much higher fracture toughness compared with pearlitic rail steels. This could avoid sudden disasters (e.g., train derailment because of rail fracture) during the operation of trains.

\section{Conclusions}

In this work, we investigated the relationship between the microstructure, mechanical stability of retained austenite, and wear resistance of a novel bainitic rail steel (namely $1380 \mathrm{G}$ ) treated by the online bainite-based quenching and partitioning (BQ\&P) concept. The conventional air cooling bainitic rail steel (namely 1280G) was also studied as a comparison. The main conclusions are given as follows:

(1) The microstructure in the $1280 \mathrm{G}$ bainitic rail steel is composed of granular bainite and coarse martensite/austenite islands. In contrast, the microstructure in the 1380 $\mathrm{G}$ bainitic rail steel is composed of fine lath bainite, lower bainite, carbon-depleted martensite, and film-like retained austenite.

(2) The retained austenite in the $1380 \mathrm{G}$ bainitic rail steel has higher mechanical stability compared with the $1280 \mathrm{G}$ variant. This is mainly attributed to the small size of the film-like retained austenite in the $1380 \mathrm{G}$ bainitic rail steel.

(3) An excellent combination of strength, ductility, and toughness was achieved in the $1380 \mathrm{G}$ bainitic rail steel (ultimate tensile strength: $1390 \mathrm{MPa}$; total elongation: $15 \%$; impact toughness: $104 \mathrm{~J}$; and fracture toughness at $-20{ }^{\circ} \mathrm{C}: 107 \mathrm{MPa} \cdot \mathrm{m}^{1 / 2}$ ). The enhanced mechanical properties are attributed to the refined microstructure and higher mechanical stability of the retained austenite.

(4) The wear mass loss of the $1280 \mathrm{G}$ bainitic rail steel $(\sim 1.03 \mathrm{~g})$ is almost twice that of the $1380 \mathrm{G}$ variant $(\sim 0.59 \mathrm{~g})$ when the cyclic number reaches $7.5 \times 10^{5}$. Meanwhile, the rolling contact fatigue cracks are rarely found in the $1380 \mathrm{G}$ rail steel. The improved performances of wear and rolling contact fatigue of the $1380 \mathrm{G}$ bainitic rail steel are attributed to the resistance of plastic deformation and crack propagation. 


\begin{abstract}
Author Contributions: Conceptualization, G.G. and X.G.; methodology, X.G. and Y.F.; validation, M.L. and Y.F.; resources, J.H.; data curation, M.L. and Y.F.; writing-original draft preparation, M.L.; writing - review and editing, M.L. and Y.F.; funding acquisition, G.G. and X.W. All authors have read and agreed to the published version of the manuscript.
\end{abstract}

Funding: This research was funded by Fundamental Research Funds for the Central Universities: No. 2021YQ001; National Key Technologies Research and Development Program of China: No. 2021YFB3703500; National Natural Science Foundation of China: No. 51771014; Joint Funds of National Natural Science Foundation of China: No. U1834202.

Data Availability Statement: Data will be made available on request.

Acknowledgments: The authors gratefully acknowledge the funding by the Fundamental Research Funds for the Central Universities (No. 2021YQ001) and National Key Technologies Research and Development Program of China (No. 2021YFB3703500). G. Gao and X. Wang acknowledge the support from National Natural Science Foundation of China (No. 51771014) and Joint Funds of National Natural Science Foundation of China (No. U1834202).

Conflicts of Interest: The authors declare no conflict of interest.

\title{
References
}

1. Olivares, R.O.; Garcia, C.I.; DeArdo, A.; Kalay, S.; Hernández, F.R. Advanced metallurgical alloy design and thermomechanical processing for rails steels for North American heavy haul use. Wear 2011, 271, 364-373. [CrossRef]

2. Pan, R.; Ren, R.; Chen, C.; Zhao, X. The microstructure analysis of white etching layer on treads of rails-ScienceDirect. Eng. Fail. Anal. 2017, 82, 39-46. [CrossRef]

3. Clayton, P.; Su, X. Surface initiated fatigue of pearlitic and bainitic steels under water lubricated rolling/sliding contact. Wear 1996, 200, 63-73. [CrossRef]

4. Bhadeshia, H.K. High Performance Bainitic Steels. Mater. Sci. Forum 2005, 500-501, 63-74. [CrossRef]

5. Yokoyama, H.; Mitao, S.; Yamamoto, S. High Strength Bainitic Steel Rails for Heavy Haul Railways with Superior Damage Resistance. Nkk Tech. Rev. 2001, 84, 44-51.

6. Sawley, K.; Kristan, J. Development of bainitic rail steels with potential resistance to rolling contact fatigue. Fatigue Fract. Eng. Mater. Struct. 2010, 26, 1019-1029. [CrossRef]

7. Pacyna, J. The microstructure and properties of the new bainitic rail steels. J. Achiev. Mater. Manuf. Eng. 2008, 28, 19-22.

8. Bevan, A.; Jaiswal, J.; Smith, A.; Ojeda Cabral, M. Judicious Selection of Available Rail Steels to Reduce Life Cycle Costs. Proc. Inst. Mech. Eng. Part F J. Rail Rapid Transit 2018, 234, 257-275. [CrossRef]

9. Kumar, A.; Makineni, S.; Dutta, A.; Goulas, C.; Steenbergen, M.; Petrov, R.; Sietsma, J. Design of high-strength and damageresistant carbide-free fine bainitic steels for railway crossing applications. Mater. Sci. Eng. A 2019, 759, 210-223. [CrossRef]

10. Hajizad, O.; Kumar, A.; Li, Z.; Petrov, R.H.; Sietsma, J.; Dollevoet, R. Influence of Microstructure on Mechanical Properties of Bainitic Steels in Railway Applications. Metals 2019, 9, 778. [CrossRef]

11. Hasan, S.M.; Chakrabarti, D.; Singh, S.B. Dry rolling/sliding wear behaviour of pearlitic rail and newly developed carbide-free bainitic rail steels. Wear 2018, 408-409, 151-159. [CrossRef]

12. Moon, A.P.; Sangal, S.; Layek, S.; Giribaskar, S.; Mondal, K. Corrosion Behavior of High-Strength Bainitic Rail Steels. Metall. Mater. Trans. A 2015, 46, 1500-1518. [CrossRef]

13. Li, Y.; Zhang, F.; Chen, C.; Lv, B.; Yang, Z.; Zheng, C. Effects of deformation on the microstructures and mechanical properties of carbide-free bainitic steel for railway crossing and its hydrogen embrittlement characteristics. Mater. Sci. Eng. A 2016, 651, 945-950. [CrossRef]

14. Gui, X.; Wang, K.; Gao, G.; Misra, R.D.K.; Tan, Z.; Bai, B. Rolling contact fatigue of bainitic rail steels: The significance of microstructure. Mater. Sci. Eng. A 2016, 657, 82-85. [CrossRef]

15. Zhang, F.C.; Zheng, C.L.; Lv, B. Effects of hydrogen on the properties of bainitic steel crossing. Eng. Fail. Anal. 2009, 16, 1461-1467. [CrossRef]

16. Gao, G.; Liu, R.; Fan, Y.; Qian, G.; Gui, X.; Misra, R.D.K.; Bai, B. Mechanism of subsurface microstructural fatigue crack initiation during high and very-high cycle fatigue of advanced bainitic steels. J. Mater. Sci. Technol. 2022, 108, 142-157. [CrossRef]

17. Zhang, R.; Zheng, C.; Chen, C.; Lv, B.; Gao, G.; Yang, Z.; Yang, Y.; Zhang, F. Study on fatigue wear competition mechanism and microstructure evolution on the surface of a bainitic steel rail. Wear 2021, 482-483, 203978. [CrossRef]

18. Schino, A.D. Analysis of phase transformation in high strength low alloyed steels. Metalurgija 2017, 56, $349-352$.

19. Gui, X.; Gao, G.; Guo, H.; Zhao, F.; Tan, Z.; Bai, B. Effect of bainitic transformation during BQ\&P process on the mechanical properties in an ultrahigh strength Mn-Si-Cr-C steel. Mater. Sci. Eng. A 2017, 684, 598-605.

20. Qiu, J.; Zhang, M.; Tan, Z.; Gao, G.; Bai, B. Research on the Microstructures and Mechanical Properties of Bainite/Martensite Rail Treated by the Controlled-Cooling Process. Materials 2019, 12, 3061. [CrossRef]

21. Van Dijk, N.H.; Butt, A.M.; Zhao, L.; Sietsma, J.; Offerman, S.E.; Wright, J.P.; Van Der Zwaag, S. Thermal stability of retained austenite in TRIP steels studied by synchrotron X-ray diffraction during cooling. Acta Mater. 2005, 53, 5439-5447. [CrossRef] 
22. Zhu, J.; Tan, Z.; Tian, Y.; Gao, B.; Zhang, M.; Wang, J.; Weng, Y. Effect of Tempering Temperature on Microstructure and Mechanical Properties of Bainitic Railway Wheel Steel with Thermal Damage Resistance by Alloy Design. Metals 2020, 10, 1221. [CrossRef]

23. Li, Q.G.; Huang, X.F.; Huang, W.G. Fatigue property and microstructure deformation behavior of multiphase microstructure in a medium-carbon bainite steel under rolling contact condition. Int. J. Fatigue 2019, 125, 381-393. [CrossRef]

24. Zhang, L.M. Analysis of Wheel/Rail Contact Stresses and Rail Corrugation. J. South West Jiaotong Univ. 2003, 38, 1.

25. Forouzan, F.; Borasi, L.; Vuorinen, E.; Mücklich, F. Optimization of Quenching Temperature to Minimize the Micro Segregation Induced Banding Phenomena in Quenching and Partitioning (Q\&P) Steels. Steel Res. Int. 2018, 90, 1800281.

26. Li, Q.G.; Huang, X.F.; Huang, W.G. Microstructure and mechanical properties of a medium-carbon bainitic steel by a novel quenching and dynamic partitioning (Q-DP) process. Mater. Sci. Eng. A 2016, 662, 129-135. [CrossRef]

27. Liu, M.; Wang, J.; Zhang, Q.; Hu, H.; Xu, G. Optimized Properties of a Quenching and Partitioning Steel by Quenching at Fine Martensite Start Temperature. Met. Mater. Int. 2021, 27, 2473-2480. [CrossRef]

28. Gao, G.; Wang, K.; Su, H.; Gui, X.; Li, Z.; Misra, R.D.K.; Bai, B. The potential of mechanical twinning in ultrafine retained austenite to enhance high cycle fatigue property of advanced bainitic steels. Int. J. Fatigue 2020, 139, 105804. [CrossRef]

29. Schino, A.D.; Gaggiotti, M.; Testani, C. Heat Treatment Effect on Microstructure Evolution in a 7\% Cr Steel for Forging. Metals 2020, 10, 808. [CrossRef]

30. Peng, F.; Xu, Y.; Gu, X.; Wang, Y.; Liu, X.; Li, J. The relationships of microstructure-mechanical properties in quenching and partitioning (Q\&P) steel accompanied with microalloyed carbide precipitation. Mater. Sci. Eng. A 2018, 723, $247-258$.

31. Sugimoto, K.I.; Kobayashi, M.; Hashimoto, S.I. Ductility and strain-induced transformation in a high-strength transformationinduced plasticity-aided dual-phase steel. Metall. Trans. A 1992, 23, 3085-3091. [CrossRef]

32. Trummer, G.; Marte, C.; Dietmaier, P.; Sommitsch, C.; Six, K. Modeling surface rolling contact fatigue crack initiation taking severe plastic shear deformation into account. Wear 2016, 352-353, 136-145. [CrossRef]

33. Chen, Y.; Ren, R.; Zhao, X.; Chen, C.; Pan, R. Study on the surface microstructure evolution and wear property of bainitic rail steel under dry sliding wear. Wear 2020, 448-449, 203217. [CrossRef]

34. Zhong, W.; Hu, J.; Shen, P.; Wang, C.; Lius, Q. Experimental investigation between rolling contact fatigue and wear of high-speed and heavy-haul railway and selection of rail material. Wear 2011, 271, 2485-2493. [CrossRef] 